\title{
Compensatory lung growth in autologus lobar implant after pneumonectomy in dogs ${ }^{1}$
}

\author{
Crescimento pulmonar compensatório em implante lobar autólogo \\ pós-pneumonectomia em cães
}

\begin{abstract}
Antônio José Maria Cataneo², Daniele Cristina Cataneo ${ }^{3}$
1. Study performed at Thoracic Surgery Division, Department Surgery and Orthopedics, School of Medicine (FMB), São Paulo State University (UNESP). Botucatu - São Paulo, Brazil.

2. Associate Professor and Coordinator of Thoracic Surgery and Post graduation Program of Surgery at FMB-UNESP. Botucatu - São Paulo, Brazil.

3. Student of Post graduation Program in Surgery at FMB-UNESP. Botucatu - São Paulo, Brazil.
\end{abstract}

\begin{abstract}
Purpose: Evaluate compensatory lung growth (CLG) in lobar transplant and see if it is similar to CLG after lobectomy. Methods: We used 48 dogs in three groups (G1=control, G2=left cranial lobectomy, and G3=pneumonectomy with reimplantation of left caudal lobe). Five months after surgery animals underwent lung scintigraphy and were then sacrificed for lung morphometric study. Results: There was no correlation between scintigraphy and lung mass or lung volume. There was both mass and residual volume CLG in the operated groups, both contralateral and epsilateral to surgery; there was no compensation for total lung capacity or compliance in the remaining caudal lobe (G2) or the reimplanted caudal lobe (G3) 5 months after surgery, there was more damage in the reimplanted lobe. As previous studies have show that CLG starts with increased mass and residual volume and that compliance is later compensated, this study seems to have documented the beginning of CLG, with lung compliance being the limiting factor of CLG after 5 months of study. Conclusion: There is CLG in both reimplanted lobe and contralateral lung but compliance is still reduced. CLG was similar in both groups but implanted lobe compliance was more prejudiced.
\end{abstract}

Key words: Animal experimentation. Transplantation, Autologous. Lung, Transplantation. Dogs.

\section{RESUMO}

Objetivo: Avaliar se existe crescimento compensatório pulmonar em transplante lobar e verificar se este crescimento é semelhante ao que ocorre após lobectomia. Métodos: Foram utilizados 48 cães, distribuídos em 3 grupos (G1=controle, G2=lobectomia cranial esquerda e G3=pneumonectomia com reimplante do lobo caudal esquerdo). Após 5 meses da cirurgia, os animais foram submetidos à cintilografia pulmonar e a seguir sacrificados para estudo morfométrico pulmonar. Resultados: Os resultados mostraram que não existe correlação da cintilografia nem com a massa nem com o volume do pulmão. Houve crescimento compensatório em massa e volume residual nos dois grupos operados, tanto no pulmão contralateral como no ipsilateral à cirurgia, não existindo até os 5 meses de estudo compensação em capacidade pulmonar total, nem em complacência pulmonar no lobo caudal remanescente do G2 e no lobo caudal reimplantado do G3, havendo maior prejuízo para o lobo reimplantado. Como estudos prévios mostram que o crescimento compensatório pulmonar se inicia com aumento da massa e do volume residual, e que a complacência é compensada posteriormente, este estudo parece ter documentado o início do crescimento compensatório, sendo a complacência pulmonar o fator limitante do crescimento compensatório após 5 meses de estudo. Conclusão: Conclui-se que existe crescimento compensatório tanto no lobo reimplantado como no pulmão contralateral, mas a complacência ainda encontra-se reduzida. O crescimento compensatório foi semelhante nos dois grupos, mas a complacência do lobo implantado está mais prejudicada.

Descritores: Experimentação animal. Transplante Autólogo. Transplante de Pulmão. Cães.

\section{Introduction}

Rejection continues to be the major problem in lung transplant due to the high antigenicity of lung tissue, we therefore believe that the best way to study compensatory lung growth (CLG) is in a transplant without rejection. Immunosuppressive drugs can influence CLG, therefore it is better to not use them. We also believe it is better to reimplant the same lobe directly after removal. In a preliminary study where we describe an experimental model of lobar transplant ${ }^{1}$, we show that although the reimplanted lobe only occupied $50 \%$ of the pleural cavity, there were no major mediastinal deviations or complications on the other side of the pleural cavity, but we did not study the CLG of this lobe. CLG was reported in the XIX century ${ }^{2}$ and since then has been studied but not so intensely as in the liver or 
kidney, therefore the phenomena involved are less known ${ }^{3}$. After ressection increase in the remaining lung should be interpreted as CLG as there is compensation for loss of volume and function, and not regeneration as occurs in the liver after partial ablation. Lung growth is similar to the kidneys with cell hypertrophy and hyperplasia. After ressection stimulation the remaining lung stretches out to completely occupy the pleural cavity. This stretching could be the start of CLG which initially would be hypertrophy with collagen and elastin synthesis; hyperplasia would occur in a final phase. Factors can influence CLG. One of these is a disharmony between lung parenchyma growth and the airway. The first is highly distendable and easily increases its volume, and the second is more rigid does not allow large alterations in volume. However, authors agree that after experimental lung ablation, mass and volume increase in the remaining lung ${ }^{4-13}$, as do DNA, RNA, and protein, suggesting cell multiplication $n^{4,8,11,14-16}$.

In previous studies with young adult rats, we have shown that CLG was so efficient that lung mass had already recovered 7 days after, and volume 30 days after surgery when around $55 \%$ of the lungs were removed. We also showed that CLG was not similar in the remaining lobes as the operated side lung had more efficient growth throughout the experiment (180 days) while contralateral lung stopped growing after 7 days $^{17}$. In relation to lung function, lung volumes and capacities which were reduced seven days after surgery, had already recovered on the 30th day postoperative (PO) and expiratory flows which were reduced on the 30th day PO were normal on the 180th day PO. Static compliance which was reduced 7 days after surgery had returned to normal by the 30th day while dynamic compliance, total lung resistance, and work performed for ventilation which were altered on the 30th day PO were normal by the 180 th day ${ }^{13}$. In a later study we showed ${ }^{16}$ that compensatory growth in rat lung mass was directly proportional to protein increase and that the lung on the operated side continued to grow until the 180th day PO while contralateral lung growth had stopped by the 30th day. Some authors have shown compensatory growth in native lung even with immunosuppressive drugs and transplanted lung rejection ${ }^{18}$. It is desirable that compensatory growth also occurs in the transplanted lung especially in adult lobar transplant or in children who are still growing. Evidence that ipsilateral lung ablation produces effective compensatory growth than in the contralateral due to pressure stimulation seems quite opportune because in transplants where the donor lung is smaller than the receptor the good transplanted lung would grow more than the native lung which is compromised. The objective of this study was to evaluate the existance of compensatory lung growth in lobar transplant and find out if it is similar to growth in the remaining analogous lobe post-lobectomy.

\section{Methods}

We used 48 adult male dogs of undefined breed between 8 - 18kg and $74-111 \mathrm{~cm}$, provided by the UNESP Central Animal House. All animals were quaranteened as demanded by the animal house, and we only used dogs which were clinically healthy. The experiment was approved by the Ethics Committee on Animal Experimentation.

There were 3 experimental groups:

Control - G1 - (n=20), submitted to lung scintigraphy and then sacrificed for lung morphometry.

Lobectomy - G2 - $(\mathbf{n = 1 4})$, submitted to left cranial lobectomy and about 5 months later underwent lung scintigraphy and were later sacrificed for lung morphometry.

Transplant - G3 - $(\mathbf{n}=\mathbf{1 4})$, submitted to left pneumonectomy and reimplantation of the left caudal lobe, and about 5 months later were submitted to lung scintigraphy and then sacrificed for lung morphometry.

\section{Surgical and anaesthetic procedure (G2 and G3)}

After approximately 12 hours fasting, animals were weighed and submitted to general endovenous anaesthesia with $30 \mathrm{mg} / \mathrm{kg}$ sodium pentobarbital, with $10 \mathrm{mg} / \mathrm{kg}$ complementation. Next animals were restrained in a Claude Bernard gutter, in right lateral decubitus and a left lateral thoracic tonsillotomy was performed. After oral trachea intubation with a Rush catheter, they were ventilated with compressed air using a Takaokaâ model 600 respirator. Left hemi-thorax antisepsis was performed with $2 \%$ iodine alcohol, a sterile surgical wrap was positioned and thoracotomy performed in the 6th left intercostal space with approximately $15 \mathrm{~cm}$ extension in skin, subcutaneous, and muscles. A Finochietto rib spreader was used. The cavity was checked for the two left lung lobes (cranial and caudal). The cranial lobe arteries and then the veins were dissected and sectioned between ligations, the cranial lobe was then removed after proximal ligation of its bronchus. Left cranial lobectomy was then completed.

Only G3 animals underwent dissection of the left main bronchus, the left branch of the lung artery, and opening of the pulmonary ligament for dissection of the left inferior lung vein. Next, the left branch of the lung artery was clamped at the most proximal point, and the start of hot ischemia was recorded. One hundred and fifty units of heparin were distally injected into the clamped artery. Then arterial flow was momentarily released for heparin mobilization towards the caudal lobe periphery. The inferior lung vein was clamped close to the left atrium without opening the pericardium and artery and vein were sectioned $0.5 \mathrm{~cm}$ distal to the clamps. The main bronchus was then clamped $1 \mathrm{~cm}$ above where it emerges from cranial lobe and the bronchus was then sectioned. Pneumonectomy was completed in G3. Caudal lobe mass were measured, then the lobe was placed in cold saline marking the start of cold ischemia. The cranial lobe bronchus stump was then removed and cold Ringer lactate ${ }^{\mathrm{O}}$ $\left(6-10^{\circ} \mathrm{C}\right)$ was injected into the caudal lobe artery at $25 \mathrm{cmH}_{2} 0$ until meat colored liquid came out of the vein. Caudal lobe reimplantation was started in the bronchus with 4-0 polypropylene thread continuous suture. The bronchus was then released and lobe ventilation began. Next the artery and vein were sutured with 6-0 polypropylene continuous suture. Before the last stitch in the vein, the artery was released to allow residual air to escape from the reimplanted lobe circulation. This marked the end of cold ischemia. $\mathrm{An}^{\circ}$ 26 Pezzer chest tube was inserted into the 3rd or 4th anterior intercostal space in all G2 and G3 animals. The thoracic wall 
was closed in layers using thick cotton to bring the ribs together and 2-0 cotton thread for musculature, subcutaneous, and skin. The chest tube was removed immediately after extubation before removing the dog from the restraining gutter. Penicillin benzatine was administered intramuscularly deep in the left thigh (600,000 units directly after surgery, and another 600,000 units the following day).

Scintigraphy: As the first procedure in G1 and approximately 5 months after surgery in G2 and G3, dogs were anesthetised as described above and scintigraphy was performed as described in a previous work (1).

\section{Sacrifice and lung measurements}

Approximately 7 days after scintigraphy, animals were again anesthetised with endovenous sodium pentobarbital $(30 \mathrm{mg} / \mathrm{kg})$ and median laparotomy was performed for bleeding by aorta section. Next, median sternotomy was performed and the lungs and heart were removed in one piece. After washing under running water, the lungs were isolated from the heart and each other by transverse section of the two bronchi close to the main carina. Lung lobes were separated and weighed with a $160 \mathrm{~g}$ capacity OWA $\mathrm{LABOR}^{\mathrm{a}}$ scale, and volumes measured by immersion in a previously calibrated flask of saline. This volume was denominated isolated lung residual volume (RV). Each lobe was then infused via the bronchus with saline at $20 \mathrm{cmH}_{2} \mathrm{O}$ until full; the bronchus was tied and lobe volume measured again. This volume was denominated isolated total lung capacity (TLC). RV was subtracted from TLC and the result divided by $20 \mathrm{cmH}_{2} \mathrm{O}$, to obtain compliance. This value was divided by residual volume to obtain specific compliance (Csp). Density of each lobe was also calculated by dividing mass by residual volume (d).

\section{Statistical analysis}

Analysis of variance was used for differences between experimental groups; $\mathrm{F}$ and p values were calculated. When $\mathrm{p}<0.05$ the Tukey test was used for differences between pairs of means. Linear correlation coefficients were determined between perfusion by scintigraphy and lung volumes and masses in the three groups, and the ' $\mathrm{t}$ ' test for dependent samples was used to compare left caudal lobe masses at the time of implant and sacrifice in G3.

\section{Results}

Ischemia time varied from 57 to 85 minutes with maximum hot ischemia time of 4 minutes. G2 animals gained around $2,1 \mathrm{~kg}$ body mass between surgery and sacrifice, and G3 gained only $0.7 \mathrm{~kg}$. There was no significant difference between groups for body mass and muzzle to anus length $(\mathrm{p}>0.05)$. The ratios for relative lung mass to body weight $(8,5 \mathrm{~g} / \mathrm{kg})$, relative lung mass to muzzle to anus length $(1.2 \mathrm{~g} / \mathrm{cm})$ were not significantly different between groups ( $p>0.05$ ). G1, G2, and G3 left caudal lobe mean lung masses were $26.27 \mathrm{~g}, 35.20 \mathrm{~g}$, and $43.19 \mathrm{~g}$, respectively; significant differences were $\mathrm{G} 1<\mathrm{G} 2<\mathrm{G} 3$ ( $<<0.001)$; RV's were $35.40 \mathrm{ml}, 44.78 \mathrm{ml}$, and $48.64 \mathrm{ml}$ respectively, significantly higher in $\mathrm{G} 2$ and $\mathrm{G} 3(\mathrm{G} 1<\mathrm{G} 2=\mathrm{G} 3$, $\mathrm{p}<0.01)$ (Figure 1$)$. Density means were $0.755 \mathrm{~g} / \mathrm{ml}, 0.789 \mathrm{~g} / \mathrm{ml}$, and $0.923 \mathrm{~g} / \mathrm{ml}$, respectively, G3 was significantly higher than the other two (G1=G2<G3, p<0.001) (fig 2). Mean TLC's were 263.05ml, $227.10 \mathrm{ml}$, and $181.71 \mathrm{ml}$ respectively; significant differences were G1>G2>G3 ( $<<0.01)$ (Figure 1). Mean Csp's were $0.338 \mathrm{cmH}_{2} \mathrm{O}^{-1}, \quad 0.208 \mathrm{cmH}_{2} \mathrm{O}^{-1}$, and $0.143 \mathrm{cmH}_{2} \mathrm{O}^{-1}$ respectively; significant differences were $\mathrm{G} 1>\mathrm{G} 2>\mathrm{G} 3$ $(\mathrm{p}<0.001)$ (Figure 2).

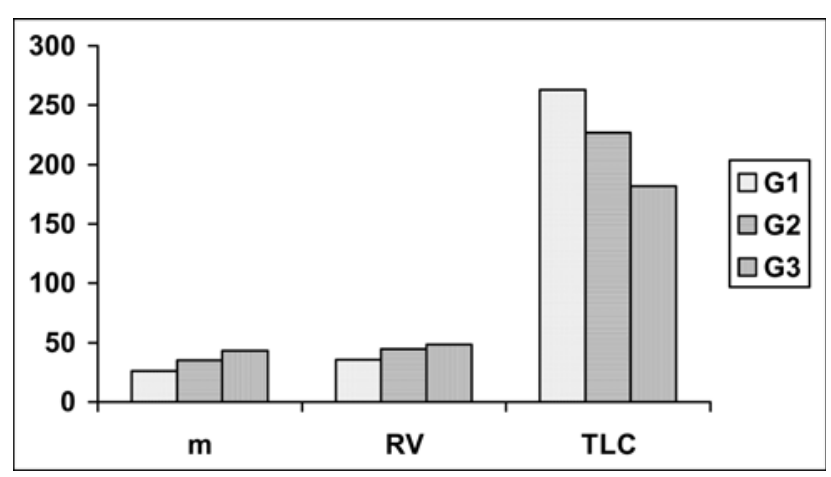

FIGURE 1 - Masse (m) in g, residual volume (RV) and total lung capacity (TLC) in ml of left caudal lobe.

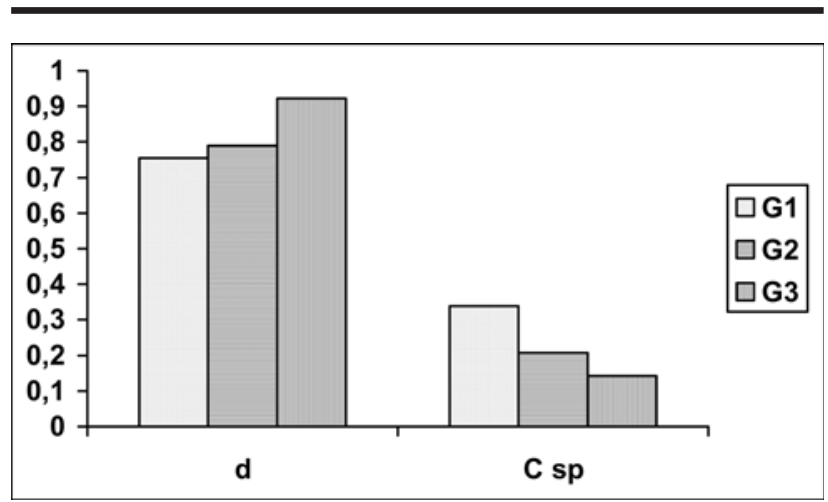

FIGURE 2 - Density (d) in g/ml and specific compliance (C sp) in $\mathrm{cm} \mathrm{H}^{-1} \mathrm{O}^{-1}$ of left caudal lobe.

G1, G2, and G3 right lung mean masses were 60.14g, $73.41 \mathrm{~g}$, and $82.23 \mathrm{~g}$ respectively, significant differences were $\mathrm{G} 1<\mathrm{G} 2<\mathrm{G} 3$ ( $\mathrm{p}<0.01)$, mean RV's were $78.65 \mathrm{ml}, 109.36 \mathrm{ml}$, and $106.14 \mathrm{ml}$ respectively, with significant difference between control and operated groups $(\mathrm{G} 1<\mathrm{G} 2=\mathrm{G} 3$, $\mathrm{p}<0.05)$ (Figure 3). Density means were $0.767 \mathrm{~g} / \mathrm{ml}, 0.718 \mathrm{~g} / \mathrm{ml}$, and $0.779 \mathrm{~g} / \mathrm{ml}$ respectively, with no significant difference between groups (Figure 4). TLC means were $684.80 \mathrm{ml}, 603.64 \mathrm{ml}$, and $587.04 \mathrm{ml}$, with no significant difference between groups $(\mathrm{G} 1=\mathrm{G} 2=\mathrm{G} 3$, $\mathrm{p}>0.10$ ) (fig 3). Csp means were $0.393 \mathrm{cmH}_{2} \mathrm{O}^{-1}, 0.249 \mathrm{cmH}_{2} \mathrm{O}^{-}$ ${ }^{1}$, and $0.234 \mathrm{cmH}_{2} \mathrm{O}^{-1}$ respectively, significantly lower in the operated groups (G1>G2=G3, p>0.001) (Figure 4).

When we compare mass and RV means between groups for entire lung, that is control group with all its lobes and operated without left cranial lobes, there was no significant difference ( $p>0.10)$, but TLC values in the operated groups were significantly lower than controls, $1167.25 \mathrm{ml}, 830.64 \mathrm{ml}$, and $777.14 \mathrm{ml}$ respectively (G1 $>\mathrm{G} 2=\mathrm{G} 3, \mathrm{p}<0.001$ ) (Figure 5). Csp mean was significantly higher in the control group $(\mathrm{G} 1>\mathrm{G} 2=\mathrm{G} 3, \mathrm{p}<0.001)$ (Figure 6). 


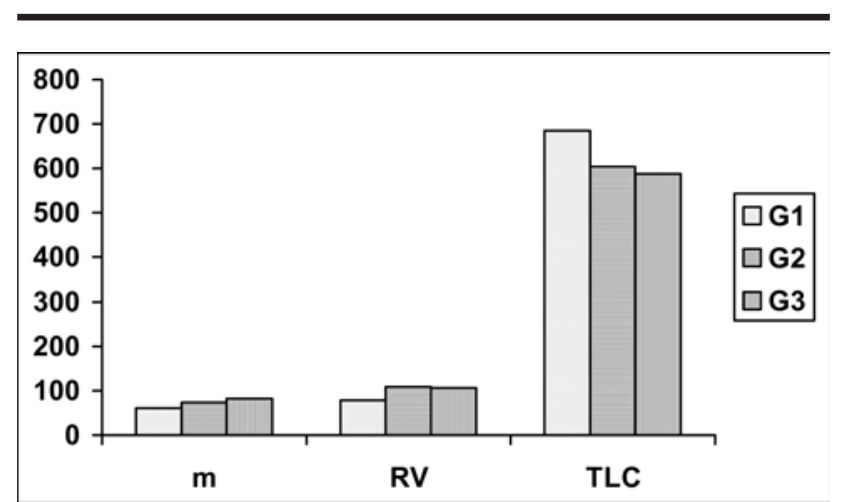

FIGURE 3 - Masse (m) in g, residual volume (RV) and total lung capacity (TLC) in ml of right lung.

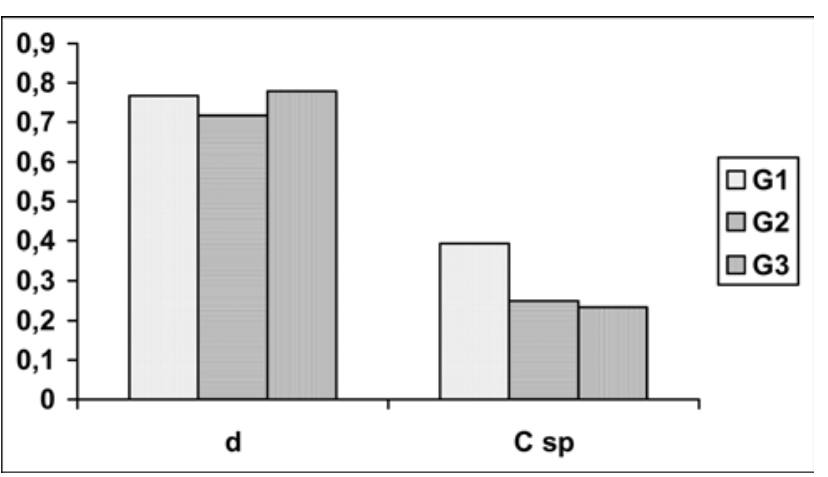

FIGURE 4 - Density (d) in g/ml and specific compliance (C sp) in $\mathrm{cm} \mathrm{H}^{2} \mathrm{O}^{-1}$ of right lung.

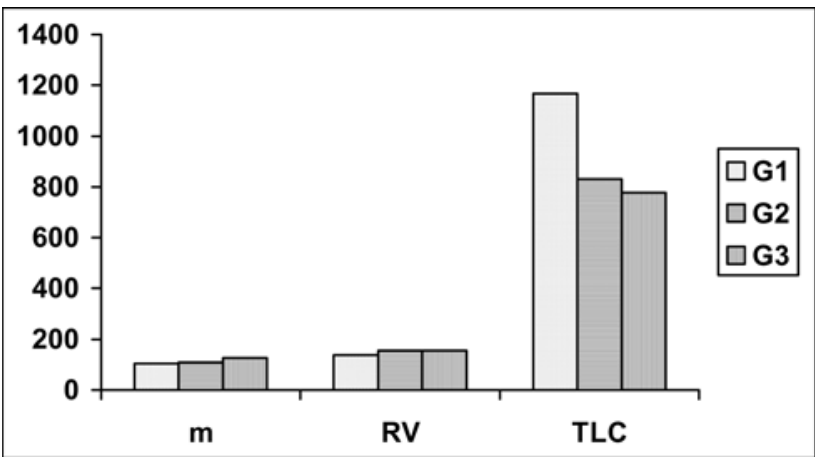

FIGURE 5 - Masse (m) in g, residual volume (RV) and total lung capacity (TLC) in ml of entire lung.

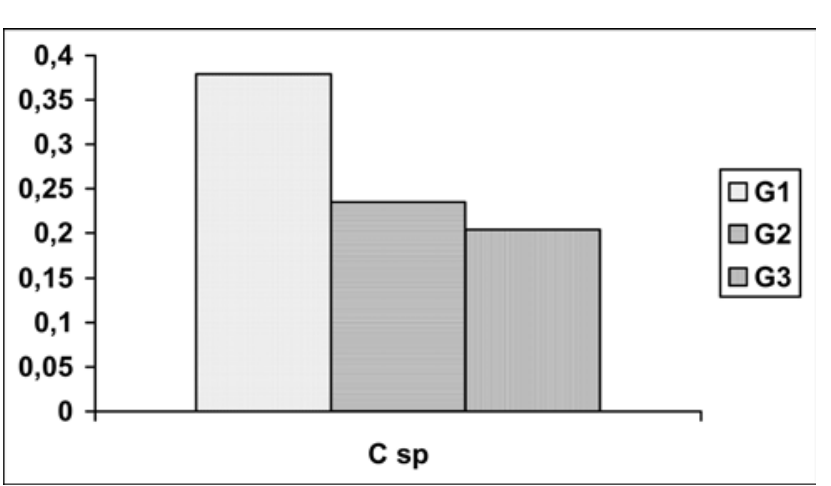

FIGURE 6 - Specific compliance (C sp) in $\mathrm{cm} \mathrm{H}^{2} \mathrm{O}^{-1}$ of entire lung.
G1, G2, and G3 mean relative perfusions in left and right lungs calculated by scintigraphy were $\mathrm{LL}=47.20 \%$ and $\mathrm{RL}=52.80 \%$; $\mathrm{LL}=28.54 \%$ and $\mathrm{RL}=71.46 \%$; and $\mathrm{LL}=18.88 \%$ and $\mathrm{RL}=81.12 \%$ respectively, significant difference between groups (LL: $\left.G_{1}>G_{2}>G_{3}, p<0.001\right),\left(R L: G_{1}<G_{2}<G_{3}, p<0.001\right)$ (Figure 7). Linear correlation between perfusion by scintigraphy and lung masses and volumes was not significant in any group. Left caudal lobe masses in G3 at time of implant were significantly lower than at sacrifice $(\mathrm{p}<0.001)$.

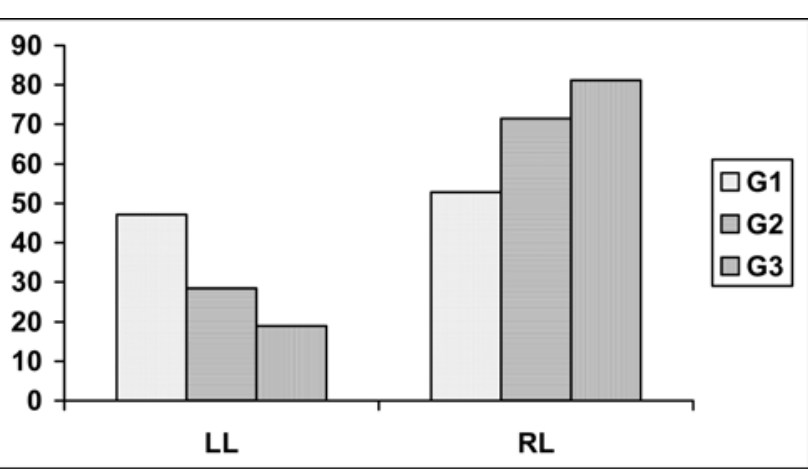

FIGURE 7 - Relative perfusion in left lung (LL) and right lung (RL) calculated by scintigraphy in \%.

\section{Discussion}

\section{Left caudal lobe}

Mean caudal lobe mass increased from G1 to G3, suggesting a higher mass compensatory growth in the reimplanted lobe than in the remaining lobe of the lobectomized animals. In G3 we were able to measure the caudal lobe before reimplantation; we could therefore compare them at time of surgery and sacrifice, they were significantly higher at sacrifice even though drier due to bleeding. This mass in the reimplanted lobe is so large that it becomes similar to control animal left lung. This could be due to compensatory growth, edema, fibrosis, etc. If it were only due to CLG, then G3 would be similar to G2, but it was higher therefore there might have been other phenomena involved in the reimplanted lobe. RV of caudal lobes in operated animals did not differ, suggesting a similar compensatory volume growth in both operated groups. But the reimplanted caudal lobe tended to have higher volume, closer to RV in whole left lung than isolated G1 caudal lobe. For TLC, volumes decrease from G1 to G3, the inverse of RV. We think that volume increase was not proportionally equal in the three groups, because of the elastic fibers stretching out during the first phase of CLG (hyperinsuflation) in G2 and G3, but they did not reach the same volume as the control group, suggesting that fiber elasticity was compromised. If we analyze left lobe specific compliance, we can see that operated animals were significantly lower than controls, and in reimplanted animals even lower still; mean Csp was 61\% in lobectomized and $42 \%$ in reimplanted animals compared to controls. This drop would be extremely great if it only represented fiber stretching by CLG, because 
if so, the insuflated lung would reach the size of the control group and as they had started from a higher RV, there would be a lower compliance of approximately 0.244 for G2 and 0.220 for G3. This may not be significant in G2 as it is only a $17 \%$ difference, but in G3 there was a 55\% difference between expected and calculated Csp. Therefore there may be other phenomena besides stretching that decrease reimplanted lobe compliance, for instance fiber thickening in the interalveolar septa ${ }^{8,11,14,19}$. It has already been reported that transplanted lung has a much more acute reduction in compliance than native lung ${ }^{20}$.

Left caudal lobe density was higher in G3 than the other two groups. This could be caused by fiber thickening of inter-alveolar septa or increased interstitial fluid. Some authors think that interstitial edema might have been responsible for thickening of interacinar septa in compensatory growth five months after pneumonectony in dogs and which had disapeared at 16 months $^{19}$. Despite little being known about lymphatic drainage adaptation in dog compensatory lung growth, in rats blood volume and interstitial fluid increase proportionally to lung parenchyma increase. Venous congestion and interstitial edema do not contribute to increased lung weight in young pneumonectomized rats ${ }^{21}$, but in transplant, due to total section of lung hilus, lymphatic drainage is interrupted and until there is lymphatic system rechannelling, edema will occur and last much longer than in pneumonectomy. In a previous work, we demonstrated that operated side lung compensatory growth in rats was more intense ${ }^{13}$ and depended on other elements besides protein ${ }^{16}$; In the contralateral side, however, growth depended on protein suggesting that on the surgery side, the remaining lobe grows with an accumulation of water or other elements with low protein concentration. This could be more intense after lobe reimplant leading to decreased lung compliance. We also observed in lobectomized rats that DNA did not significantly increase in the remaining lobes but RNA increased reaching values similar to the not operated groups; this suggests that compensatory growth is due more to increased cell volume than increased cell number suggesting lung tissue hypertrophy and not hyperplasia. This could be the cause of low compliance in reimplanted lobes. Corroborating this idea, Duebener et al. ${ }^{22}$ showed that stretching of the alveola septa 14 weeks after lobar transplant in growing pigs; this explains the decrease in lung compliance.

\section{Right lung}

Mean right lung mass is higher in the operated groups; this is very pronounced in G3 which is about 36\% heavier than controls. Langenburg et al. ${ }^{18}$ also reported increased mass in contralateral lung 10 months after transplant. Operated right lung RV's are similar and both significantly higher (approximately 36\%) than controls; showing similar compensatory volume growth in contralateral lung of both lobectomized and reimplant groups. Langenburg et al. ${ }^{18}$ reported only a tendency towards increased functional residual capacity in the lung contralateral to the transplanted lung already rejected after surgery. Their results were probably not significant because they worked with a small number of animals as several authors have already shown mass and volume compensatory growth in lung contralateral to pneumonectomy ${ }^{19,21,23}$. There was no significant difference in TLC between the three groups showing that despite operated animal RV's being higher they did not manage to distend beyond control TLC values. If we analyze right lung Csp, we find no difference between operated groups but they are both significanty lower than controls; as right lung TLC was similar in the three groups, and RV was lower in G1 we understand that operated animal elastic fibers were already distended in RV and therefore unable to exceed control group TLC. It therefore seems that CLG occurs to fill the cavity from hypertrophy as fibers elongate but they can only reach the primitive position, and no further. We notice that right lung densities are similar in all three groups therefore an increased volume corresponds to a proportional mass increase. As density was measured in RV and this volume was already higher in operated animals than controls, the proportional mass increase could be by thickening of inter-alveolar septa. Other authors ${ }^{18}, 10$ months after transplant rejection, noticed that contralateral lung compliance was similar to controls. They also noticed hyperinflation by increased alveoli surface. In rats ${ }^{24}$, we showed that compensatory growth in lung contralateral to surgery occurred with increased proteins and RNA, but not DNA, also with cellular hypertrophy and not hyperplasia, and this growth maintained constant protein concentration showing that there were no other elements growing in a higher proportion as seemed to occur in the ipsilateral lung.

\section{Whole lung}

Whole lung masses and RV's were both statistically similar in all three groups, and since the left cranial lobe was missing in operated animals, we understood that there was RV and mass compensatory growth. This increase was approximately equal to the mass and RV of the cranial lobe removed from G2 and G3. In rats, this has been reported by several authors ${ }^{6,10,13}$, and was proportional to protein increase $^{16}$. Therefore if compensatory growth in dogs is similar, this mass increase may be due to increased protein synthesis. This would be higher in G2 epsilateral remaining lobe or G3 reimplanted lobe which had more stimulation to grow by stretching out in an attempt to completely fill the pleural cavity. This phenomenon was due to collagen and elastin synthesis ${ }^{4}$. Whole TLC is significantly higher in G1; as RV in the three groups are similar, G1 Csp is higher than in operated animals; the caudal lobes of operated animals were responsible for this low Csp which was more pronounced in G3. Whole lung density is also higher in G3 due to the the left caudal lobe. Protein increase may lead to thickening of the inter-alveolar septa ${ }^{8,11,14}$ which would result in decreased lung compliance. This would be more pronounced in reimplanted lobes. In trilobectomized young adult rats, lung compliance was reduced on the first postoperative days, but on the $30^{\text {th }}$ day dynamic and $180^{\text {th }}$ day static compliance, were not significantly different to controls $^{13}$. Similar results could probably be obtained in a group of dogs, but over a longer time as dog longevity is approximately 7 times higher than the rat. TLC was still 
reduced 7 days after surgery in rats despite normalized RV, but on the $30^{\text {th }}$ day it was normal ${ }^{13}$. Other authors have shown that this compensation may occur before the $14^{\text {th }}$ postoperative day in rats ${ }^{10}$. Perhaps TLC compensation time in dogs is longer than our study period, this is why it was not detected.

\section{Lung scintigraphy}

In the control group, despite higher captation in the right lung, it was not significantly different from the left but in operated animals the right lung captation was significantly higher than the left. Scintigraphy did not detect CLG and no correlation was found between scintigraphy and lung mass and volume in any group; this demonstrates that perfusion scintigraphy under these conditions is not representative of lung parenchyma levels. One reason that may alter the result in operated dogs is anaesthesia, because to perform scintigraphy dogs were previously anaesthetized which leads to a superficial breathing ${ }^{1}$. As the left lung in operated animals had less compliance than the right, ventilation damage to the left was much higher and by the Euler and Liljestrandt law, perfusion should also decrease which would lead to reduced radionuclide drug captation by the left lung.

There are other factors influencing captation besides compliance because in controls there was no significant correlation between captation with scintigraphy and lung volume and mass, and one of the elements that can influence this result is decubitus because lung perfusion depends on gravity.

\section{Conclusion}

There is CLG in transplanted lobe and lung contralateral to transplant, but lung compliance is still reduced five months after surgery. In lobectomized and transplanted animals CLG of contralateral lung was similar but on the operated side reimplanted lobe lung compliance is much more prejudiced than the lobe remaining after lobectomy.

\section{References}

1. Nagao RK, Cataneo AJM. Autologus lobar lung implant after pneumonectomy: experimental model in dogs. Acta Cir Bras. [serial on the Internet] 2005 July-Aug;20(4). Available from URL: http://www.scielo.br/acb

2. Haasler G. Ueber compensatorishe hypertrophie der lunge. Virchows Arch Pathol Anat Physiol. 1892;128:527-36.

3. Thurlbeck WM. Postpneumonectomy compensatory lung growth. Am Rev Resp Dis. 1983;128:965-7.

4. Addis T. Compensatory hypertrophy of the lung after unilateral pneumonectomy. J Exp Med. 1928;47:51-6.

5. Cohn R. Factors affecting the postnatal growth of the lung. Anat Rec. 1939;75:195-205.

6. Romanova LK. Regenerative hypertrophy of the lungs in rats after one-stage removal of the entire left lung and the diaphragmatic lobe of the right lung. Bull Exp Biol Med. 1961;50:1192-7.

7. Sery Z, Kepri E, Obrucnik M. Morphometric analysis of late adaptation of the residual lung following pneumonectomy in young and adult rabbits. J Thorac Cardiovasc Surg. 1969;57:549-57.

8. Buhain WJ, Brody JS. Compensatory growth of the lung following pneumonectomy. JAppl Physiol. 1973;35:898-902.

9. Tartter PI, Goss RJ. Compensatory pulmonary hypertrophy after incapacitation of one lung in the rat. $\mathrm{J}$ Thorac Cardiovasc Surg. 1973;66:147-52.

10. Nattie EE, Wiley CW, Bartlett D Jr. Adaptive growth of the lung following pneumonectomy in rats. J Appl Physiol. 1974;37:491-5.

11. Cowan MJ, Crystal RG. Lung growth after unilateral pneumonectomy quantitation of collagen synthesis and content. Am Rev Respir Dis. 1975;111:267-77.

12. Wandel G, Berger LC, Burri PH. Morphometric analysis of adult rat lung after bilobectomy. Am Rev Respir Dis. 1983;128:968-72.

13. Cataneo AJM, Curi PR, Reibscheid SM. Alterações funcionais do aparelho respiratório pós-trilobectomia pulmonar: estudo experimental no rato. J Pneumol. 1989;15:1-7.

14. Romanova LK, Leikina EM, Antipova KK. Nucleic acid synthesis and mitotic activity during development of compensatory hypertrophy of the lung in rats. Bull Exp Biol Med. 1967;63:303-6.

15. Brody JS, Burki SR, Kaplan N. Desoxyribonucleic acid synthesis in lung cells during compensatory lung growth after pneumonectomy. Am Rev Respir Dis. 1978;117:307-16.

16. Ruiz RL Jr, Curi PR, Cataneo AJM. Compensatory lung growth lung mass and protein content in trilobectomized rats. Acta Cir Brás. 1996;11:127-32.

17. Cataneo AJM, Curi PR, Reibscheid SM. Alterações morfológicas do aparelho respiratório pós-trilobectomia pulmonar: estudo experimental no rato. J Pneumol. 1988;14:121-6.

18. Langenburg SE, Blackbourne LH, Buchanan S A, Mauney, MC, Kim, SS, Sinclair, KN, Kern, JA, Teja, SS, Tribble, CG, Kron, I . Compensatory Growth of Porcine Right Lungs after Chronic Rejection of Transplanted Left Lungs. Ann Thorac Surg. 1995;59:28-32.

19. Hsia CCW, Herazo LF, Fryder-Doffey F, Weibel R. Compensatory Lung Growth Occurs in Adult Dogs after Right Pneumonectomy. J Clin Invest. 1994;94:405-12.

20.Crombleholme T M, Adzick NS, Hardy K, Longaker, MT, Bradley, SM, Duncan, BW, Verrier, ED, Harrison, M.R. Pulmonary lobar transplantation in neonatal Swine: A model for treatment of Congenital Diaphragmatic hernia. J Pediatr Surg. 1990;25:11-8.

21.Doerschuk CM., Sekhon HS. Pulmonary blood volume and edema in postpneumonectomy lung growth in rats. J Appl Physiol. 1990;69:1178-82.

22.Duebener LF, Takahashi Y, Wada H, Tschanz SA, Burri PH, Schäfers HJ. Do mature pulmonary lobes grow after transplantation into an immature recipient? Ann Thorac Surg. 1999;68:1165-70.

23.Georgopoulos D, Mink S N, Oppenheimer L. How is maximal expiratory flow reduced in canine postpneumonectomy lung growth? JAppl Physiol. 1991;71:834-40.

24.Ruiz RL Jr, Burini RC, Cataneo AJM. Compensatory lung growth: lung protein, DNA and RNA contents in trilobectomized rats. Acta Cir Bras. 1998;13:18-25. 


\section{Correspondence:}

Antônio José Maria Cataneo

Thoracic Surgery Discipline of the Surgery and Orthopedics Department

School of Medicine of Botucatu - São Paulo State University - UNESP

18618-970 Botucatu - SP Brazil

Phone: (5514)3811-6230

Fax:(5514)3815-7615

acataneo@fmb.unesp.br
Conflict of interest: none

Financial source: none

Received: April 05, 2005

Review: May 10, 2005

Accepted: June 14, 2005

\section{How to cite this article:}

Cataneo AJM, Cataneo DC. Compensatory lung growth in autologus lobar implant after pneumonectomy in dogs. Acta Cir Bras. [serial on the Internet] 2005 Sept-Oct;20(5). Available from URL: $\underline{\text { http://www.scielo.br/acb }}$

\section{RECOMENDAÇÕES AOS AUTORES}

Os DESCRITORES/KEY WORDS são essenciais para a acessibilidade e recuperação dos artigos.

O DeCS [Descritores em Ciências da Saúde] facilita o acesso à informação e guia os usuários na localização e seleção da informação científica.

Incluir termos, nos descritores, que não estão no DeCS impedem a localização do artigo.

Portanto se os autores desejam que seus artigos sejam encontrados torna-se imperioso pesquisar no DeCS os termos corretos: acessar www.bireme.br e clicar em Terminologia em Saúde. A seguir Consulta ao DeCS e por fim Consulta por Palavra, nos idiomas inglês, espanhol e português. 